\title{
THE FEAR OF THE LORD AS THE 'PRINCIPLE' OF WISDOM
}

\section{By HENRI BLOCHER}

After decades of comparative neglect, Old Testament wisdom literature has come into vogue. In the "prolegomenon" of a recent symposium, James L. Crenshaw observes, with a smile, that "Wisdom's shade tree has suddenly become a haven for many, and the excitement of new discovery fills the air"; he hastens to add: "So too, do the excesses of exuberant converts". ${ }^{1}$

So long as the recital of God's saving actions monopolized attention, ${ }^{2}$ and the idea of general revelation was looked upon with suspicion, wisdom could not receive its share. But a change in theological climate cannot solve all the problems; especially it cannot annul the obvious difference between the teaching of the wise and the main discourse of the Covenant, election, and messianic hope. On the contrary, the difference is all the more evident when Israel's wisdom is in the lime-light alongside Israel's faith. In fact, there is a running debate on the relationship of the former to the latter, or on the integration of wisdom in the religion of the Old Testament. Typically, Albert de Pury deals with the relationship between wisdom and revelation as with the relationship between the non-specific and what is claimed to be highly specific. ${ }^{3}$ Horst D. Preuss has raised a powerful protest against Von Rad's praise of wisdom, and has made himself the champion of the

* Delivered at Tyndale House, Cambridge, on 8th July, 1977.

' James L. Crenshaw (ed.), Studies in Ancient Israelite Wisdom Ktav, New York (1976) 2.

${ }^{2}$ Ibid, 1; similarly R. B. Y. Scott, 'The Study of the Wisdom Literature' Interpretation 24(1970) 21.

3 'Sagesse et révélation dans l'Ancien Testament', Revue de Théologie et de Philosophie third series 27 (1977) 3. 
view that wisdom remained pagan at heart, essentially alien to true faith in the LORD, under a very superficial "Jahwesierung". 4

The saying "The fear of the LORD is the principle of wisdom" can hardly escape notice as a link between wisdom and a main religious theme. Most scholars agree to consider it as such, whether they see it as the expression of an essential solidarity, ${ }^{5}$ or as the mark of the first stage in a process of theologization, ${ }^{6}$ the instrument with which wisdom was definitely "exorcized", 7 or, with Preuss, a vain and deceiving tag, a Gothic porch added to a Romanesque church, which can mask but cannot change its real character. ${ }^{8} \mathrm{~A}$ closer examination of the saying would therefore seem opportune.

Even apart from its relevance to present debates, the oft-quoted apophthegm would deserve special study. Many writers call it the motto, ${ }^{9}$ or the keyword, ${ }^{10}$ of wisdom writings. Even W. Zimmerli, although his whole emphasis falls on the alleged anthropocentric nature of wisdom, acknowledges it to be "doubtless the highest maxim, the queen of all the rules of direction." 11 G. von Rad boldly voices his conviction that it is both Israel's entire theory of knowledge " in a nutshell", and "Israel's most special possession." "12 Structural analysis of the Book of Proverbs can buttress a high valuation of the importance of the maxim: it is found near the beginning and near the end of the first booklet,

4 'Alttestamentliche Weisheit in christlicher Theologie?' in Questions disputées d'Ancien Testament Bibl. Ephem. Th. Lovan. 23, Leuven University Press \& J. Duculot, Gembloux (1974) 165-181. This work recapitulates earlier ones.

${ }^{5}$ E.g. Frank Michaëli, 'La Sagesse et la crainte de Dieu' Hokhma 2 (1976) 40.

$6 \mathrm{~J}$. L. Crenshaw, op. cit. 24.

7 The word is used by Raymond Tournay, 'Proverbes 1-9, première synthèse théologique de la "tradition des Sages" ' Concilium 20 (1966) 54.

${ }^{8}$ Preuss, art. cit. 176.

${ }^{9}$ E.g. Derek Kidner, The Proverbs TOTC Tyndale Press, London (1964) 59. Also Berend Gemser, Sprüche Salomos HAT J. C. B. Mohr (Paul Siebeck) Tübingen (1937) 13; R. B. Y. Scott, Proverbs, Ecclesiastes (Anchor Bible) Doubleday, New York (1965) 36.

${ }^{10}$ Berend Gemser, 'The Spiritual Structure of Biblical Aphoristic Wisdom', in Crenshaw (ed.), op. cit. 219 (reprinted from Gemser's collected essays Adhuc loquitur, E. J. Brill, Leiden (1968).

"The Place and Limit of the Wisdom in the Framework of the Old Testament Theology' in Crenshaw (ed.), op. cit. 319 (reprinted from SJT 17(1964); German original in Les Sagesses du Proche-Orient ancien, Presses Universitaires de France, Paris (1963) 121-136, quoted 127.

${ }^{12}$ Wisdom in Israel ET by James D. Martin, SCM Press, London (1972) 67f. 
ch. 1-9, thus forming an inclusio; moreover, the virtuous woman in the last poem probably stands as a personification of the fear of the LORD (she is said to be ידאמת ת יהוה Pr. 31:30, the feminine participle construct has the same form as the noun) and thus a subtle inclusio is found again, with Dame Wisdom at the beginning of the book. ${ }^{13}$ It is not by chance that a parallel association with the fear of the Lord occurs in the other two wisdom writings of the Old Testament: with Becker, it is possible to maintain that Job 28:28, "The fear of the Lord, that is wisdom", far from being an unfortunate addition, is genuine, indeed "the proper goal of the poem"; 14 with Becker also one can plead that Ecclesiastes 12:13 is in harmony with the very personal diction of Qoheleth, and with his spiritual world, that he himself has left it in the epilogue as a key for the understanding of his work. ${ }^{15}$ At least as we have them, all three wisdom books stand witnesses to that thought, the fear of the LORD as the principle of wisdom.

Our study will follow a very simple route. It will first focus our attention on the words and notions used in the aphorism, considered separately. Then it will try to ascertain its meaning in the places where it is found. We shall briefly meditate on its bearing and connections in the wider contexts of the "wisdom movement" and of Old Testament thought, before casting a glance on possible reflections and counterparts in the New Testament.

One point of method, only, need not detain us long. We encounter the saying in forms which are not strictly identical. What are we to do with this diversity? The phrasing which we

${ }^{13}$ Joachim Becker, Gottesfurcht im Alten Testament, Analecta Biblica Pontifical Biblical Institute, Rome (1965) 211. Becker relies specially on Patrick W. Skehan, 'A Single Editor for the Whole Book of Proverbs' in Crenshaw (ed.), op. cit. 329-340 (rep. from $C B Q$ Monograph series 1, 15-26), by whose reckonings Prov. 1:7 is the seventh line from the start and 9:10 the seventh line before last in these chapters (330).

${ }^{14}$ Op. cit. 245: "scheint v. 28 vielmehr das eigentliche Ziel des Gedichtes zu sein." Otto Procksch also had given a favourable verdict: Theologie des Alten Testaments C. Bertelsmann, Gütersloh (1950) 477. Becker remarks that v.27 would not make a satisfactory conclusion; the prosaic introductory formula of $v .28$ allows the saying to stand out in sharper relief. Contra: most critics; e.g. von Rad, op. cit. 149.

${ }^{15} \mathrm{Op}$. cit. 254f. Becker mentions on the same side Wildeboer and Zapletal. He writes: "Er selbst (Qohelet) hat im Epilog einen Schlüssel zum Verständnis seiner oft verwirrende Äusserungen hinterlassen" (255). The use of the article, הזלחים, is typical. Contra: "all critics", Louis Derousseaux claims, La Crainte de Dieu dáns l'Ancien Testament, Lectio divina, Cerf, Paris (1970) 343. 
have been using is an acceptable translation of Psalm 111:10a. In Proverbs 1:7 and 9:10 it is slightly altered: "knowledge" for "wisdom" in the first case; "beginning" rather than "principle" in the second. Job 28:28 simply equates "fear" and "wisdom", and Ecclesiastes 12:13 keeps the thought of wisdom implicit. Proverbs 15:33 is nearer to the "main" form of the maxim, with the word מרסט, education, training, discipline, instead of "principle". We shall take these various statements, especially those in Proverbs and Psalm 111, as variants of the same saying, presumably with the same meaning. Privilege will go to likeness over against differences. We shall appreciate nuances as facets of the one truth implied. Permission so to do comes from the stylistic habits of the sages. They were wont to pile up quasi-synonyms, so that, according to Günther Wanke's judgement, "precise differentiation of the terms is barely possible and probably not intended." "16 Lévêue speaks of their "congenital imprecision": their effort was "to silhouette things rather than to define notions." "17 Some have labelled their use of parallelism "stereometric": they constantly chiselled the various faces of the same thought. ${ }^{18}$ Repetition, and repetition in other words, served the authority of a מעל : it was not only a means of emphasis, and a part in the ceremonial of dignified speech, ${ }^{19}$ but it suggested the statement to be a definitive conclusion, and a full account of reality - from whatever angle you look at it, so it stands. We shall interpret accordingly.

The "fear of the LORD", ידרית ', is the stablest element in the saying. In Job 28:28, if it is not a case of the קר replaces the divine

${ }^{16}$ S.v. $\varphi \circ \beta \varepsilon ́ \omega \quad \varkappa \tau \lambda \quad$ (O.T.) TDNT IX ET by G. W. Bromiley, Eerdmans, Grand Rapids (1974) 202.

17 'Le Contrepoint théologique apporté par la réflexion sapientiale' in Questions disputées, op. cit. 185.

${ }^{18} \mathrm{G}$. von Rad, op. cit. 13, 27. On parallelism as a universal feature of oral (folk) wisdom, see A. Barucq, 'Proverbes (Livre des)' Dictionnaire de la Bible, Supplément VIII fasc. 47 (1972) 1414.

${ }^{19} \mathrm{G}$. von Rad, op. cit. 54.

${ }^{20} \mathrm{It}$ is possible according to Becker, op. cit. 246 (100 mss read יהוה). 
name because Job and his friends are not Israelites. Only in Ecclesiastes is the wording different, but then, the text can be considered as more than a variant.

The theme of the fear of the LORD, or of God, ${ }^{21}$ has been thoroughly scrutinized by several scholars in recent years, especially in the major monographs of J. Becker ${ }^{22}$ and L. Derousseaux ${ }^{23}$ who builds on the work of Becker and Plath. The later studies have broken the rule of Rudolf Otto's mysterium tremendum et fascinosum, ${ }^{24}$ and they have shown conclusively that words deriving from the same root (here איר: ) cannot always be given the same semantic breadth. So the participle $\$$ \ר does mean "terrible" but the noun יראה never means "terror"; it is used in a weaker moral or religious sense; Derousseaux would acknowledge only once (Ex. 20:20) the meaning "sacred fear" to it. ${ }^{25}$

Apart from references to "sacred fear", Becker distinguishes three main meanings: moral (the fear of God is upright behaviour); cultic (the fear of God is the proper form of worship); legal (nomistisch - the fear of God is the observance of the law). Very decidedly, he puts the fear of the Lord in wisdom writings in the moral category. ${ }^{26}$ One can argue for an ethical understanding of the fear of the LORD from the general tenor of wisdom admonitions, and from the

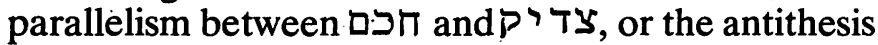
between חכם andע mentioned just before the second occurrence of our saying in Proverbs (9:9). In Job 28:28, the parallel phrase is the ethical "turning from evil"; in Psalm 111:10, the practice of the פים פד 7 ("them");" in Ecclesiastes 12:13, obedience to the commandments.

${ }^{21}$ The change of divine name does not affect significantly the use of the phrase: $\mathrm{H}$. A. Brongers, 'La Crainte du Seigneur (Jir'at Jhwh, Jir'at' Elohim)' OTS V (1948) 163 n.11.

${ }^{22}$ Op. cit. (supra n.13).

${ }^{23}$ Op. cit. (supra n.15).

${ }^{24}$ See especially Derousseaux, ibid. 20f, 360ff, et passim.

${ }^{25}$ Ibid. 168 (cf. 99).

${ }^{26}$ Op. cit. 210,261 . The LXX often changed the meaning into a legal one (238-241).

${ }^{27}$ M. Saebo, s. v. חדם , Theologisches Handwörterbuch zum Alten Testament I Ernst Jenni and Claus Westermann (ed.), Chr. Kaiser \& Theologischer Verlag, München \& Zürich (1971) 562, 564f.

${ }^{28}$ With Becker, op. cit. 270f, it is wiser to keep the MT (against LXX, Syr., Vulg., (ע) 
Categorization, however can become a snare if one maintains it too rigidly. Becker's distinctions may be too clear-cut, especially as they are based on current, but questionable, source-criticism hypotheses. ${ }^{29}$ Instead of "cultic" fear Derousseaux prefers to speak of "Covenantfear" (mostly in Deuteronomy) with the connotations of Covenant devotion and loyalty. ${ }^{30}$ Wanke questions the division between cultic and legal fear. ${ }^{31}$ In comments on particular texts, stronger and deeper meanings of fear are perceived. In Joshua 24, fearing YHWH means unconditional submission to him and rejection of other gods, as well as moral and cultic obedience. ${ }^{32}$ In the story of Abraham's testing, Genesis 22, the fear of God is neither conformity to moral law, nor terror before the unknown tremendum; Muslims call Abraham the Muslim, the text of the Bible shows in him the model of true Godfearers $!^{33}$ Derousseaux expresses well how יר מהב מבד wa with the recognition of the absolute sovereignty of YHWH..$^{34}$ Transitions can be found, as in Exodus 20:20, between sacred fear and moral obedience. Becker himself affirms that the numinous element, although weakened, can always be revived,,$^{35}$ and that prophets deliberately used that possibility (Je. 5:22;10:7; Is. 57:11) ${ }^{36} \mathrm{He}$ relativizes his own divisions in acknowledging that the fear of God always retains the character of that unconditional reverence and submission which is typical of the Old Testament. ${ }^{37}$ In many cases a mediating meaning will be appropriate, with the emphasis on taking God seriously, in

${ }^{29}$ Derousseaux, op. cit. $10 \mathrm{n} .23$, thinks Becker's distinctions are too clear-cut. However he relies on source analysis even more than Becker in his attempt at reconstruction of a history of the fear of God; in spite of the brilliancy of the work, one remains sceptical.

${ }^{30}$ Loc. cit. and $100 f$.

${ }^{31}$ Art. cit. 201.

${ }^{32}$ Derousseaux, op. cit. 191f.

${ }^{33}$ Ibid. 174-178.

${ }^{34}$ Ibid. 220, 256.

${ }^{35} \mathrm{Op}$. cit. 80 (but Brongers is ill-inspired when he says, op. cit. 158: "il reste toujours quelque chose de sinistre"!).

${ }^{36}$ Ibid. 82f.

${ }^{37}$ Ibid. 81: “. . . unbedingter Ehrfurcht und Unterwüftigkeit gegenüber Gott, der dem Alten Testament eigen ist." 
his commands, and threats, and promises. ${ }^{38}$

In wisdom literature, also, the ethical sense is too narrow. G. Fohrer finds that fear of the LORD in wisdom teaching "always denotes piety. It does not mean terror but religious awe . ..". ${ }^{39}$ R. N. Whybray stresses its relationship to religious education, and would include in it "obedience, loyalty, worship, sacrifice and love" - it is Yahwism! $!^{40}$ A. M. Dubarle sees humility as a basic component of that fear, a recognition of the distance between the Creator and his creature, opposed to pride and mingled with trust. ${ }^{41}$ Surely the association of fear and humility in Proverbs 15:33 is far from accidental. In Proverbs 22:4, we would take ירזת ידת as an apposition to עy רזי attitude of the despisers, בז ה ה 13:13;14:2; and even 1:7, the first expression of the motto! In Proverbs 9:10, the parallel clause, knowledge of the Holy One (קדעים), since God's holiness is his transcendence, could also suggest humility before him: it is knowledge, or acknowledgement, of the distance which separates man from the Lord. In Psalm 111:10, the association with the $\$>7$ Jof verse 9 shows that the element of sacred fear before the Holy One was also felt. ${ }^{43}$ The whole theme of the discourse in Job 28 is man's inability to reach out to the Creator's wisdom; the last verse opposes to man's vain efforts towards the knowledge of Elohim a wisdom born of humility. ${ }^{44}$ As to Ecclesiastes, many writers have felt the power of his sense of God's transcendence, near to numinous dread in $3: 14 ;{ }^{45}$ although Franz Delitzsch'

${ }^{38}$ An instance of this is the opposition of the fear of God and the fear of man; in 1

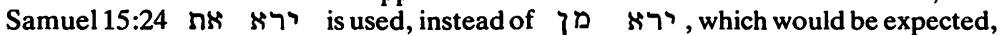
in order to bring out the contrast fear of God/fear of man more forcibly

(Derousseaux, op. cit. 144f). In Je. 26:19 the "fear" of Hezekiah seems rather to mean his taking God's word seriously than his respect of morals (Becker, op. cit. 207ff) or his faithfulness to the Covenant-God (Derousseaux, op. cit. 254).

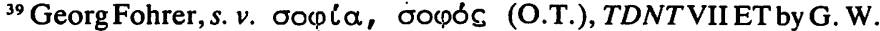
Bromiley, Eerdmans, Grand Rapids (1971) 487.

${ }^{40}$ Wisdom in Proverbs. The Concept of Wisdom in Proverbs 1-9, SBT 45, SCM Press, London (1965) 96.

${ }^{4}$ Les Sages d'Israël, Lectio divina Cerf, Paris (1946) 45, cf. 57f.

42 With Becker, op. cit. 224.

${ }^{43} \mathrm{Ibid}$. 272. Becker further argues that verses $9 \mathrm{c}$ and $10 \mathrm{a}$ must go together in the acrostic.

${ }^{44}$ A similar thought can be found in Job 37:24 if one follows LXX and Syr. and

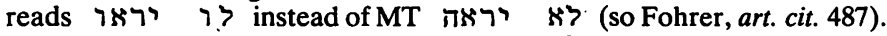

${ }^{45}$ E.g., recently, H.-P. Stähli, s. v. יראה Theologisches Handwörterbuch zum A.T. I 776, referring to $12: 13$; J. L. Crenshaw, op. cit. 29. Even H. D. Preuss admits: "Gottesfurcht bleibt als letzter Halt", op. cit. 170. 
statement is hyperbolic, that Ecclesiastes is "The Song of Songs of the fear of God", ${ }^{46}$ the epilogue statement, if seen in the light of the whole book, must also recall man's utter dependence on God and his need to submit to God.

In another direction also, it may be necessary to go beyond the simple moral sense. In Proverbs 1-9, according to Derousseaux, the fear of YHWH takes on a more intellectual meaning, as a gift which illuminates man's intelligence. ${ }^{47}$ This may be compared with the more objective meaning which is found in Job 15:4 where יר (p) (שיחה (parallel to almost stands for the theology of Job's friends ${ }^{48}$ In Psalm 19:10 the meaning is certainly objective: the law as it determines man's right attitude before God, and so probably also in Psalm 34:12. ${ }^{49}$ Becker would accept an objective meaning for Psalm 111:10, fear being a metonymy for law. ${ }^{50}$ It must be remembered that just as fides quâ and fides quae creditur cannot ultimately. be separated (for fides quâ without fides quae would vanish totally), the subjective and objective meanings cannot ultimately be severed from each other.

\section{II}

The concept of דִ דעת - with as a quasi-synonym stands out also as a typical Old Testament theme. As a central and unifying concept, it has no equivalent in-the intellectual traditions of Egypt or Mesopotamia. ${ }^{51}$ In spite of the abundant research of the last decades, it is not so easy to define as might be thought. ${ }^{52}$ On the lower meanings of the word, or the word-group, however, there seems to be effortless agreement. Wisdom is skill, expertise, or

${ }^{46}$ In his Commentary of 1875,190 , as quoted by B. J. Oosterhoff, De Vreze des Heren in het Oude Testament, Kemink, Utrecht (1949) 98.

${ }^{47} \mathrm{Op}$. cit. 324: "la crainte de Yahvé a une acception plus intellectuelle: elle conduit peut-être à la sagesse, mais elle est surtout un don qui vient de Yahve, pour éclairer l'intelligence." Becker admits "von einem 'intellektualisierenden' Zug der Jahwefurcht in Spr 1-9 zu sprechen", op. cit. 217.

${ }^{48}$ Derousseaux, op. cit. 333.

${ }^{49}$ Oosterhoff, op. cit. 76.

${ }^{\text {so }} \mathrm{Op}$. cit. 267. Contra: Oosterhoff, loc. cit.

${ }^{51}$ M. Saebo, art. cit. 564 ("Wohl anders ...").

52 R. N. Whybray, The Intellectual Tradition in the Old Testament, BZAW 135, W. de Gruyter, Berlin \& New York (1974) 3 (n.3: Crenshaw criticized von Rad for giving too broad a definition, but Crenshaw's is too narrow). 
competence. Above all, wisdom is the king's requirement: the ability to govern the people, to judge and to plan. His counsellors ought to be wise, although it is still a matter of controversy, in spite of Jeremiah 18:18, whether there existed a class of men professionally or institutionally called "the wise." 53 All will also grant that higher חכמה was viewed first as a matter of $\chi \cup \beta \varepsilon \rho \cup n \sigma \iota s$, of steersmanship in life, to use the LXX translation of Proverbs 1:5b.

The main question for our inquiry is this: was wisdom only practical? Was it restricted to counsels for life-management, laws of success and rules of behaviour? Or did a theoretical element interfere? The contents of so many chapters in the Book of Proverbs would lend credibility to the idea of a purely

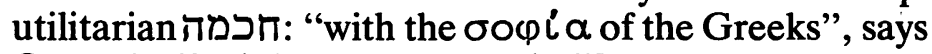
Oosterhoff, "it had nothing to do." 54 Upon closer examination, however, one has to ease the narrow coat of a purely practical concept of wisdom - lest it become a straitjacket! With Michaëli, one has to allow also for a "didactic notion", and a "theological" one. ${ }^{55}$ Several considerations support this broader view. As Fohrer perceives, "the impulse towards academic wisdom was there from the outset, as may be seen from the ancient notes on Solomon's wisdom;"56 Solomon's Onomastica, his lists which he established in botanic and zoological realms according to 1 Kings $4: 33$, show that there was also an effort towards encyclopedic classification. ${ }^{57}$ Furthermore, even practical advice entails a "theoretical" confidence in cosmic order; Preuss, who dislikes the trait, stresses that wisdom, already in isolated proverbs, has a powerful tendency to system, he even says: to dogma. ${ }^{58}$ In Proverbs 1-9, wisdom interprets itself, emphatically, as the

${ }^{53}$ The book quoted in the foregoing note is an attempt to show that this common opinion is groundless.

${ }_{54}$ Op. cit. 85 ("niets te maken"). Fohrer, at first, opposes it to a "theoretical mastery of questions of life and the universe", art. cit. 476.

${ }^{\text {ss }}$ Art. cit. 41f. Fohrer distinguishes a greater number of "layers", art. cit. $480 \mathrm{ff}$.

${ }^{56}$ Art. cit. 488, cf. 481.

${ }^{57}$ Müller, s. v. חדם , Theologisches Wörterbuch zum Alten Testament II, fasc. 8, Johannes Botterweck \& Helmer Ringgren (ed.), W. Kolhammer, Stuttgart-Berlin - Köln - Mainz (1976) 932. John F. Priest, 'Where is Wisdom to be Placed?' in Crenshaw (ed.), op. cit. 287 (rep. from Journal of Bible and Religion 31 (1963) 275-282), reacts against Scott's scepticism about Solomonic origins.

${ }^{58}$ Art. cit. 169: "Weisheit hat damit per se den Drang zum System in sich. zum Dogma, und der Zug zu Systematisierung ist keineswegs in ihr erst ein zweiter oder gar ein die ursprüngliche Weisheit entstellender Schritt." 
source of harmony and the principle of coherence in God's work of creation (3:19f; 8:22-31), and this association is also found in prophets (Is. 40:12ff; Je. 10:12). Now the one-time critical dogma that creation was a late development of Exodus faith no longer stands unchallenged; powerful rebuttal has come from Hans Heinrich Schmid and others. ${ }^{59}$ Wisdom can hardly be separated from a world-view, a view of the world shaped by belief in creation. The great discourse in Job 28 rebukes the ambitions of a very speculative kind of wisdom: this is proof that the word incan be used for an endeavour mainly theoretical; the alternative in verse 28 need not be confined to the ethical sphere: the emphasis is on modesty. Proverbs 1:6 may suggest another aspect of wisdom:; to provide hermeneutical and logical nimbleness, ability to think straight through paradoxes and symbolism. One may compare such an aim with those intellectual gymnastics which the writer to the Hebrews wanted to promote (Heb. 5:14), and which, in spite of the mention of good and evil, seem to correspond to his interpretation of Melchizedek. Wisdom, or דעת (if there is a nuance, it may be a greater emphasis on what lies beyond the practical), cannot be confined to morals in Proverbs 1. Moreover, the very maxim in 1:7, together with the praises in the following chapters, demonstrate an elaborate reflexion on the nature and status of wisdom: ${ }^{60}$ we are far from a simple string of practical counsels for daily life. ${ }^{61}$ We may safely conclude that Old Testament חכמה also satisfied man's impulse to think and to know without the fateful division between $\vartheta \varepsilon \omega \rho i \alpha$ and $\pi \rho \tilde{\not} \xi \iota \varsigma$ which we inherited from the Greeks.

\section{III}

The third important word of our maxim in Proverbs 1:7 and Psalm 111:10, is רצי רית, a word of moderately frequent use. With somewhat puzzling laxity, many writers seem happy to leave its precise meaning in the "motto" of wisdom literature

${ }^{59} Z T h K 70$ (1973) 1-19, as quoted and approved by Crenshaw, op. cit. 27, who quotes also Ludwig. Similarly, J. F. Priest, art. cit. 286, arguing from the Song of Deborah, Gen. 14:22, Pr. 14:31 and 20:12.

${ }^{60}$ Zimmerli, 'Place and Limit . . .' op. cit., 322.

${ }^{61}$ Fohrer, art. cit. 482: "a comprehensive theological system is thus forged." 
quite uncertain. Brongers, already, mentioned the common translation, but added that the word means also "the chief or esential part, what comprises everything"; ${ }^{2} \mathrm{H}$. Renard offered either "perfection" or "beginning". ${ }^{63}$ Still recently, Saebo has "beginning" or "sum", 64 and Andre Caquot hesitantly favours "culmination". ${ }^{65}$

Lexicographers (and Bible translators generally) seem to show more reserve and generally prefer the simple sense "beginning": so, without other comment, the Brown-DriverBriggs and Koehler-Baumgartner Lexicons. The GeseniusBuhl Lexicons allows as a possibility "best part or fruit";66 Zorell prefers "initium, principium" (even "primus gradus") but he admits that "aliquid ... primarium, praecellens, optima pars" may be the meaning in our texts. ${ }^{67}$ A survey of Old Testament usage makes it difficult to give to the word "ראשית the meaning of "sum" or "totality", of "crown" or "culmination": no clear instance can be adduced; Daniel

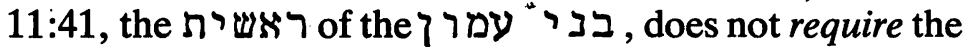
meaning "sum" ("first fruits" or "best part" would well enough fit the text) and ת רצ might be amended to ת ית in a famous article, when he transferred to $ת$ י

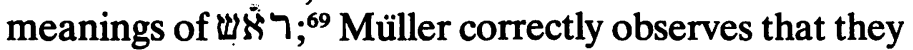
correspond only in the areas of time and value. ${ }^{70}$ One may grant him that "abstractly used"ת ת רית may take on the meaning of "Inbegriff", substance or essence, ${ }^{71}$ as in Jeremiah 49:35 (the substance of the power of Elam); yet the

${ }^{62}$ Art. cit. 167: "la chose principale, l'essentiel, ce qui renferme tout,"

${ }^{63} \mathrm{H}$. Renard, Le Livre des Proverbes, in La Sainte Bible VI A. Clamer (ed.), Letouzey \& Ané, Paris (1943) 44.

${ }^{64}$ Saebo, art. cit. 565: Anfang oder Summe.

${ }^{65}$ Andre Caquot, 'Sur la sagesse israëlite', Positions Luthériennes 24 (1976) 139: "peut-être ... le comble de la sagesse".

${ }^{66}$ G-B, s. v.: "doch ist hier auch: bester Teil, Hauptsache od(er) edelste Frucht, möglich."

${ }^{67}$ Franciscus Zorell, Lexicon hebraicum et aramaicum Veteris Testamenti, Pontifical Biblical Institute, Rome (1965) s. $v$.

${ }^{68} \mathrm{G}-\mathrm{B}$ and $\mathrm{KB}$.

69 'Christ as the APXH of Creation' JTh S 27 (1926) 175f; the argument that aram. resh stands for both hebrew words may be relevant to Pauline exegesis (Burney's interest), but not to that of Prov.

${ }^{70}$ Müller, s. v. ר ר , Theologisches Handwörterbuch zum Alten Testament II (1976) 709.

${ }^{71}$ Ibid. $710 \mathrm{f}$. 
primary meaning is what comes first, in a temporal sequence or in appreciation (the best thing, as Am. 6:6 "the best oil"), with the additional technical sense of the first fruits offering (Ex. 23:19, etc.).

What is the most likely sense in the maxim? Can it be that fear of the LORD is the first-fruits, or the "best fruit" produced by wisdom ${ }^{72}$ ? In favour of this rendering one can point only to Proverbs 2:1-5, where understanding of the fear of the LORD will reward those who seek wisdom. Yet, even in this passage, knowledge-and-fear of the LORD is the end of the search and could be the beginning of wisdom, or, more probably its essence. And no variant of our saying puts the fear of the LORD in the situation of the goal to be attained through wisdom; it can hardly be the meaning in Psalm 111 and Proverbs! Three main possibilities are left: (a) beginning; (b) chief or choicest part; (c) substance, or essence. In favour of the first of these three, many writers wield a formidable argument: the parallel word in Proverbs 9:10 is the nonambiguous תחלה, beginning; in spite of Loretz, it is difficult not to interpret 1:7 and 9:10 in the same way $;^{73}$ so do, e.g., Oosterhoff, von Rad, Becker, Michaëli. ${ }^{74}$ The second interpretation, chief part (NEB mg) or choicest part, would well agree with the preceding verses in Proverbs 1 , as well as with current usage of $ת$ ר variants (especially 9:10), and nowhere do we see wisdom divided into "parts". The last understanding can appeal to Job 28:28, where fear is wisdom, and to the frequent synonymity between the two terms in Proverbs 1-9. ${ }^{75}$ However, it involves a rarer use of the word, and it interprets the more precise by the less precise.

The arguments in favour of the first of the three renderings definitely prevail. Yet "beginning" lacks the valueconnotation of $ת$ ר ראי. Furthermore, it can be

${ }^{72}$ B. Gemser in Crenshaw (ed.), op. cit. 219, combines "basic principle" and "best fruit".

${ }^{73}$ O. Loretz, 'Il meglio della sapienza è il timore di Jahvè' Bibbia e Oriente 2 (1960) 211 understands that the fear of the LORD is better than all the advantages mentioned in $\operatorname{Pr} .1: 2-6$; in 9:10 he supplies already: already at the beginning is the fear of the LORD decisive ("già all'inizio della sapienza il timore di Jahvè a una parte determinante").

${ }^{74}$ Oosterhoff, op. cit. 85; von Rad, op. cit. 66; Becker, op. cit. 214f; Michaëli, art. cit. 42.

${ }^{75}$ E.g. 1:29. See Becker, op. cit. 219, 223; Wanke, art. cit. 202. 
misinterpreted as only the "first step", "primus gradus" (Zorell), which one can leave behind. The synonymity of fear of the LORD and wisdom (Job 28:28) excludes this. So does also Proverbs 15:3, where מר confirms that the saying is concerned with access to wisdom, but shows that fear of the LORD is a permanent determination. When wisdom is in question, priority is likely to be logical as much as chronological. The best translation would seem to be, therefore, principle (with the nuance that separates principium from initium). Many scholars in fact adopt it, with Kidner, who explains principle", ${ }^{76}$ or they come very near to it, as Wanke who speaks of a "kernel-motive" in the thinking of a systematic whole. "Principle" can suit also Proverbs 4:7, which we would translate: "The wisdom"; the acknowledgement of one's need of wisdom and the willingness to renounce everything for its sake may not be a far cry from the fear of the LORD, as the principle of wisdom.

\section{IV}

The ground-work being laid with the study of the three main constituents of the maxim, we may hope to understand their combination. While avoiding ungraceful eclecticism, we should not exclude a priori ramifications in the meaning intended by the inspired teachers of wisdom.

"The fear of the LORD is the יתר an ironic dart flung at the ungodly: those who lack the fear of God are ignorant of the very $\mathrm{ABC}$ of wisdom; they lie below beginning-level! Such was apparently, Calvin's interpretation. ${ }^{78}$ It would agree with the deriding of the fools, in Proverbs 1:7b, who despise education ( $c f .9: 7,8$ before

${ }^{76} \mathrm{Kidner}$, op. cit. 59. Vulg. has principium. Several French versions have "principe": Bible du Rabbinat français, Bible de Jérusalem. Traduction Oecuménique de la Bible. Müller, s. v. חדם art. cit. (n.57) 938 accepts principium. Scott, op. cit. 33: the first principle (37: he comments: "the necessary premise"). Wanke, loc. cit. n.68, uses "principle".

${ }^{77}$ Müller, s. v. . ' ר , art. cit. (n.70) 712: it serves "dem systematischen Erfassen eines Ganzen von einem Kernmotiv her." Arthur Weiser, Die Psalmen, ATD (1950) 465 uses "Grundlage"; A. Barucq, Le Livre des Proverbes, Sources Bibliques, Gabalda, Paris (1964) 49, "base".

${ }^{78}$ In his Commentary on the Psalms, on Ps. 111:10. 
9:10). However, it would imply the meaning "primus gradus" for ראשית, which is unlikely. The saying, also, seems to play a more positive part. Let us remember, only, that one can hear polemical overtones: ${ }^{79}$ the sharp antithesis between true wisdom and its opposite, which is peculiar to Biblical wisdom, ${ }^{80}$ is very present in the background.

"The fear of the LORD is the principle of wisdom" could restrict wisdom to moral obedience, at least subordinate knowledge to ethical character: to be wise is to do good. Obviously this interpretation is the first to present itself if one gives to the fear of God and to wisdom essentially ethical meanings. In the two "critical" works of Job and Ecclesiastes, it would be in harmony with the context: more ambitious forms of wisdom are but feeding on the wind; man-sized wisdom is turning from evil, obeying the commandments. However, in Psalm 111 the recollection of the terrible works of God (in verse 9) would suggest a deeper meaning. The moral interpretation seems too short in the three instances in Proverbs $(1: 7 ; 9: 10 ; 15: 33)$. It would involve the meaning "sum", or at least, "substance", for רצית, whereas "principle" is to be preferred. Our investigation has also led us to give broader significations to חכמה and

. Ethics do come into play, but only in so far as they are inseparable from religion.

"The fear of the LORD is the principle of wisdom" might well invite the wise to modesty, to the confession of the limits they cannot trespass: wisdom acknowledges human lowness. The saying would parallel the $\mu \eta \delta \varepsilon \nu$ ö $\gamma \alpha \nu$ of the Greeks

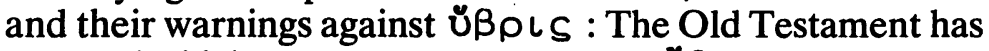
no word which corresponds precisely to. $\mathrm{J}_{0} \iota \mathrm{\varsigma}$, but it has many to stigmatize pride, arrogance, insolence.$^{81}$ If the "motto" of wisdom is there to humble the would-be wise, it again agrees with the context in Job and Ecclesiastes: man is not the measure, but he is measured, under the unsearchable

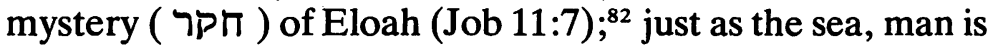

${ }^{79}$ Von Rad, op. cit. 67.

${ }^{80}$ Barucq, Proverbes 34.

${ }^{81}$ On the whole theme, see Paul Humbert, 'Démesure et chute dans l'Ancien Testament', in Maqqél shaqédh, Hommage à Wilhelm Vischer, Causse - Graille Castelnau, Montpellier (1960) 63-82.

$82 \mathrm{~J}$. Lévêque, art. cit. 188. 
limited by the divine $P \Pi ;{ }^{83}$ God is in heaven, man is merely man (Ec. 5:2). This interpretation takes into account the paralellism between fear of God and humility in Proverbs 15:33 and 22:4, and its opposition to a scornful attitude; in Proverbs 1:7, Becker would have "fear" correspond to "fool", and "beginning" to "despise", ${ }^{84}$ this is strained, but since או יל used here has the note of insolence, ${ }^{85}$ both the noun and the verb describe that attitude of heart which is the opposite of the fear of the LORD, the opposite of humility. Other passages in Proverbs recommend not to be wise "in one's own eyes" $(3: 7 ; 28: 26)$, and $21: 30$ reminds man of his nothingness before God: "There is no wisdom, no discernment, no counsel, in the presence of the LORD", which Kidner brilliantly paraphrases: no true synthesis, analysis or policy. ${ }^{86}$

In view of the importance of that theme, it is wiser not to speak of an erôs of knowledge in Biblical:הכד Tמas Von Rad does. ${ }^{87}$ On the other hand, one never meets the Socratic irony: knowledge is knowledge of one's ignorance, ${ }^{88}$ and much less the docta ignorantia of later mystiicism. The aphorism of Proverbs 1:7 and variants is basically positive, in association with discourses which praise all the advantages of wisdom. One surmises that the call to humility is but one side of the coin, corresponding only to the more negative aspects of the fear of the LORD.

"The fear of the LORD is the principle of wisdom" underlines that wisdom has a religious foundation: ${ }^{89}$ man can know reality in truth, and thus steer his course in life, only if he proceeds in the knowledge of God, and acknowledges his absolute lordship. This interpretation agrees best with the more probable meaning of the three parts of the saying, especially with the fuller meaning of יראת יהר: positive devotion to God as well as negative renunciation of pride. The

${ }^{83}$ Ibid. 196.

${ }^{84}$ Op. cit. $215 \mathrm{f}$.

${ }^{85}$ As Kidner shows, op. cit. 41.

${ }^{86}$ Ibid. 146.

${ }^{87}$ Von Rad, op. cit. 309f. He refers to 1 Kings 5:9 but the "breadth of heart" given Solomon is simply vast knowledge described in hyperbolic terms (and a gift from God).

${ }^{88}$ Von Rad, 'La sagesse en Israël' Revue Théologique de Louvain 2 (1971) $74 \mathrm{f}$ comes very near to it: "he only is truly wise who does not believe himself to be wise."

${ }^{89}$ Thus Lévêque, art. cit. 198. 
LXX translation of Proverbs 22:4 would summarize it:

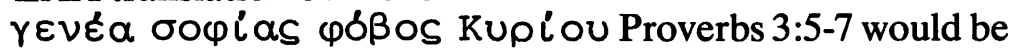
the fullest commentary in the book: the principle of wisdom is the renouncing of autonomy, and trusting acknowledgement of the LORD at every step of one's practical or intellectual progress. Thus understood, the saying explains the emphasis on wisdom as a gift of God, something coming from him, ${ }^{90}$ as in Solomon's case, and according to Proverbs 2:6. One can even go one step further and speak, with Kidner, of a dependence on revelation. ${ }^{91}$ Such a phrase fits the inspiration claims of Elihu ${ }^{92}$ the general context of Psalm 111, and the description of wisdom as a quasi-prophetess in Proverbs 1-9. In that light, "fear of the LORD" may have an objective aspect, and wisdom an all-embracing character, intellectual as well as practical.

Several writers concur in this understanding. Gerhard von Rad sees that the Old Testament ignores our modern tension between faith and thought, reason and revelation: ${ }^{93}$ that knowledge for the inspired sages never functioned in an autonomous way; ${ }^{94}$ that wisdom was a "form of Yahwism", 95

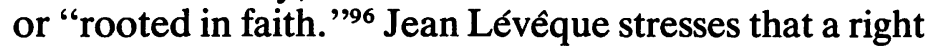
attitude before God is necessary for a sound appraisal of reality; ${ }^{97}$ the wise did not develop a "neutral or independant psychology or sociology: their reflexion about man was of faith. ${ }^{98}$ Frank Michaëli reaches similar conclusions, and he notes how they contrast with the modern mind. ${ }^{99}$ We would follow them.

J. Becker discerns with perspicacity that the writer of Proverbs 1 and 9 does not wish to compare wisdom and fear of God: to put the one above the other; ${ }^{100}$ he believes, however, 489 .

${ }^{9}$ Op. cit. 59 (synthesis 38).

${ }_{92}$ Von Rad, Wisdom 56.

${ }_{93}$ Ibid. 61.

94 Ibid. 68.

95 Ibid. 307.

96 'La Sagesse ... .' art. cit. 71.

${ }^{97}$ Art. cit. 187: "Seule une juste attitude devant Dieu permet une saine appréciation du réel."

${ }_{98}$ Ibid. 194: "un élément essentiel demeure constant, c'est que la réflexion sur l'homme constitue une démarche de la foi."

${ }^{99}$ Art. cit. 43.

${ }^{100}$ Op. cit. 217. 
that he uses the saying to commend wisdom, not the fear of God, whereas in Job 28 and in Psalm 111 it is the reverse, there is a concern to commend the fear of the LORD. ${ }^{101}$ Is the idea of commendation ('Empfehlung') so helpful here? The saying in Proverbs is a foundational and programmatic thesis, on the principle of wisdom. In Job, the emphasis is more critical: it opposes one kind of wisdom to another. And in the Psalm, the well-known maxim is quoted in the spirit of praise: the psalmist marvels at the fullness of the LORD's benefits, that his revelation reverently received makes one truly wise.

\section{IV}

If the aphorism of Proverbs 1:7 means that wisdom depends on a religious motive, what is the function of the saying in a larger context? Our interpretation opens the door to a fairly common historical construction: according to many scholars, the older form of wisdom was secular, or of pagan origin; it was later nationalized and a yahwistic stamp was put on it, especially by means of our saying. ${ }^{102} \mathrm{~W}$. McKane emphasizes the newness of the religious מר and the influence of prophets. ${ }^{103}$ Whybray speaks rather contemptuously of the "well-known cliche" which pointed to a "new way" for obtaining wisdom, ${ }^{104}$ and testified "to the new "orthodox status' of the wisdom teacher and his school." 105 Alphonse Maillot traces back the origin of the problem to the duality of $\mathrm{El}$ and YHWH, and he seems to deplore that, progressively, and in Proverbs 1:7 especially, a confusion was made between the two ${ }^{106}$ For such writers, the fear of the LORD can hardly be called the actual principle of Old Testament wisdom: the maxim borders on wishful thinking, if not deceitful advertisement.

Scholarly opinion, however, has increasingly recognized the frailty of this historical hypothesis. Crenshaw concludes

${ }^{101}$ Ibid. 213, 217, 246, 273.

${ }^{102}$ A representative statement in Fohrer, art. cit. 483. Gemser, Sprüche, op. cit. 13, feels there is an apologetic "tendenz" in the saying of Prov. 1:7.

${ }^{103}$ Proverbs. A New Approach, OTL, SCM Press, London (1970) 264, 368.

${ }^{104}$ The Intellectual Tradition 9.

105 Wisdom in Proverbs 98.

${ }^{106}$ Alphonse Maillot, 'La Sagesse dans l'Ancien Testament' Etudes Théologiques et Religieuses 51 (1976) 340ff. 
that it is "neither possible to write a chronological history of the development of wisdom literature, nor to place each of the forms within its proper setting." 107 Since W. F. Albright broke the spell - "While Proverbs may contain a very high proportion of matter originating outside of Israel, it is saturated with Israelite theism and morality"108 — several writers have shown that even the "earliest" parts or strata of the Book of Proverbs presuppose the faith in YHWH, that even there God is not, to borrow F. D. Kidner's phrase, "an afterthought", ${ }^{109}$ and that much interchange must have taken place between priests, prophets and wise men. ${ }^{110} \mathrm{We}$ would point to Isaiah 29:13-14, as a further confirmation; the prophet rebukes both a hypocritical fear of him (taught by the precept of men) and a wisdom which God will confound: these verses show that in Isaiah's century the fear of the LORD and wisdom had been joined together long enough for hypocritical corruption to take place.

One word may be added concerning the original character of Old Testament religion and wisdom, for this is the underlying issue in the debate. We find it surprising that the faithful of the LORD, with all their loathing of idolatry and their consciousness of Covenant-privilege, included in their wisdom books the words of Agur and Lemuel, or were hospitable to the influence of Amen-em-ope. Yet our very surprise should be taken as a monitory symptom: is our approach in accord with theirs? Advocates and critics look first of all to differences in language and logic for possible proof that the contents of the Old Testament were unique in the Near-Eastern setting. The whole method of Horst D. Preuss is a review of allegedly original features: in each case he shows that there are analogies outside of Israel, and therefore he concludes that Old Testament wisdom remained pagan at bottom. ${ }^{111}$ Similarly, Albert de Pury finds nothing

${ }^{107}$ Op. cit. 22.

${ }^{108}$ Wisdom in Israel and in the Ancient Near-East (presented to H. H. Rowley)

VTSuppl 3, M. Noth \& D. Winton Thomas (ed.), E. J. Brill, Leiden (1955) 13.

${ }_{109}$ Op. cit. 32.

${ }^{110}$ So Barucq, in his commentary, op. cit. 23ff, and art. in DBS 1408, 1412, 1440f;

Carl Keller in Maqqél shaqédh 95 n.21; J. F. Priest, op. cit. 284 (forceful); D. A.

Hubbard, 'The Wisdom Movement and Israel's Covenant Faith' TB 17 (1966) 3-33 (esp. 18); Lévêque, art. cit. 187 (emphatic).

${ }^{111}$ Art. cit. $171 \mathrm{ff}$. 
really specific in Israel's faith except the jealousy of YHWH. ${ }^{12}$ But should the comparative approach reign supreme? It is significant indeed that none can quote a saying "The fear of Marduk (or Baal or Râ) is the principle of wisdom"; yet the men of the Bible would not have been embarrassed by such a saying, they would have denounced and rejected it because Marduk is no god, Marduk is a Nothing! In other words, the uniqueness of truth among human errors and demonic lies is truth - it may not be obvious in its expression (cf. 2 Cor. 11:13 f.). Untruth is not just something else than truth: it is truth corrupted, and sometimes so with subtlety. In this light, the existence of scattered similarities to Biblical truths in the ancient NearEast could be considered as glimpses of God's original revelation, with no damage done to uniqueness, and Godfearing teachers of wisdom in Israel could assimilate insights which Egyptians had gained by God's common grace, just as their fathers had spoiled these Egyptians' riches. The weakness of the comparative approach is that it tends to take the field of phenomena as the ultimate reference for judgement. But Veritas index sui et falsi! Reverent reference to the LORD first is the principle of wisdom! When one abides by this principle, he can appreciate (and there is plentiful evidence for him then to canvass!) how darkened and distorted the truth of God has been in nations deprived of special revelation. ${ }^{113}$

Inner inconsistencies would raise real difficulties. Is the fear of the LORD principle for wisdom only in wisdom writings? Distinct echoes may be heard in the Law and the Prophets that suggest that wisdom per se was not thought to be alien to true Torâ religion and prophetic faith. Since Lindblom's study, ${ }^{114}$ numerous contacts have been recognized between prophets and the wisdom movement. A. de Pury underlines the use by 8 th century prophets not only of sapiential

${ }^{112}$ Art cit. 40ff.

${ }^{113}$ Barucq, Proverbes 37, stresses that Proverbs have their own "physiognomy". Derousseaux. op. cit. 41f, 65, arrives at conclusions on the fear of the gods in Egypt and Mesopotamia which imply a long distance from the Old Testament.

${ }_{114}$ Johannes Lindblom, 'Wisdom in the Old Testament Prophets' in VTSuppl 3, 192-204. 
techniques, but of sapiential ideas of right and wrong. ${ }^{115}$ Hosea's emphasis on knowledge make the last verse of the book a fitting addition, if it be an addition. Isaiah's interest in wisdom is such that many follow Fichtner in supposing that Isaiah belonged to the class of the wise when he was called to the prophetic ministry. ${ }^{116}$ His preaching would well illustrate the motto of Proverbs: he repeatedly thunders against the "wisdom" born of pride, of those who are wise in their own eyes $(5: 21 ; 19: 11 \mathrm{ff} ; 29: 4 ;$ cf. $47: 10 \mathrm{ff})$, and having noted, with some irony, that God, too, is wise (31:2), he binds wisdom and knowledge to the fear of the LORD (33:6): even for the coming Son of David, whose 'delight' or 'inspiration' הר יחר will be in the fear of the LORD (11:2f). ${ }^{117}$ The whole passage, Isaiah 8:10ff reads as a commentary on the principle of true wisdom: the counsel of man shall not stand, but to fear God means, for his disciples (למד י), to go to the divine instruction (תר (ת) and thus to receive light at last. The wisdom call of Isaiah 50:10 is written in the same spirit, while it conjoins the fear of the LORD and obedience to his Servant. ${ }^{18}$ Jeremiah in his polemics against the ruling class in Jerusalem had the opportunity also to criticize their worldly wisdom (8:8f); his great passage 9:23f 'Let not the wise man glory in his wisdom, but in this, That he understands and knows me, that I am the LORD', can be taken as an expanded form of the wisdom motto. ${ }^{119}$ When one turns to the Law, one thinks first of Deuteronomy 4:6 (cf. 29:29) where the body of God's directions for his people receives the name of wisdom: it will be your wisdom in the sight of the nations; the mention of the nations reminds us of the international character of wisdom: it is when the law of God is developed in the form of wisdom that it can be appreciated as universal truth and norm.

${ }^{115}$ Art cit. $35 \mathrm{f}$ (see his n.6).

116 Johannes Fichtner, 'Isaiah Among the Wise' in Crenshaw (ed.), op. cit. 429-438 (transl. from $T h L Z 74$ (1949) 75-80). Crenshaw, Ibid. 10, indicates J. William Whedbee and Joseph Jensen as recent supporters. Robert Martin-Achard was an earlier one, 'Sagesse de Dieu et sagesse humaine chez Esaie in Maqqél shaqédh, 137f; he notes that $\mathrm{E}$. Sellin had already made the suggestion in 1935. Becker, op . cit. 258f, is not inimical to the suggestion, and cites R. T. Anderson, JBL 79 (1960) $57 \mathrm{f}$.

${ }_{117}$ On this passage, see Derousseaux, op. cit. 273.

${ }^{118}$ On this passage, see Becker, op. cit. $256 \mathrm{f}$.

119 Von Rad, Wisdom 103, favours its authenticity. 
But even before, in Genesis 2-3, sapiential motifs appear, ${ }^{120}$ although discreetly. The Paradise story, with its constant play on words, shows a high degree of literary חכמה. In view of the identification of the Tree of Life with wisdom in Proverbs, one can see in the trees of Genesis the antithesis of the false wisdom of autonomy and the true wisdom which leads to life, in dependence on God. And one could cite also the biography of Joseph, the Godfearing (Gn. 42:18) Model of the wise, to confirm that the maxim of Proverbs 1 spreads its roots and branches in various parts of the Old Testament.

As it is with texts, so with themes. The role of the fear of the Lord in wisdom is intimately connected with main tenets of Old Testament faith. It agrees with its anthropology, with its unified view of the inner man and its concentration in the heart (cf. Pr. 4:23): if the heart both thinks and wills, and is man's religious organ, how could thought function independantly? A real autonomy of reason would require a real division between man's faculties; in fact there is no such thing as "reason" but only men, or hearts, reasoning - and as they make moral choices and commit themselves ultimately, so they are able to reason. ${ }^{121}$ More radically: it flows as a necessary consequence from creational monotheism. We already noted the solidarity between wisdom and belief in creation, which need not be considered late in Israel. ${ }^{122}$ If the whole of reality comes from one wise and sovereign Lord, who has ordered all things, reality is all of one piece; nothing is independent of God, and nothing can be truly interpreted independently of God. This conviction was so strong, as Lévêque notes, that even when they faced the reality of evil, the wise resisted the temptation to attribute it to a mythical, uncreated power, a power able to cross God's purpose. ${ }^{123}$ One can even go further and relate to radical monotheism the so-called "secular" aspect of wisdom: it could not surface with

${ }^{120}$ Already Dubarle, op. cit. 57; Luis Alonso-Schökel, 'Sapiential and Covenant Themes in Genesis' in Crenshaw (ed.), op. cit. 468-480, esp. $472 \mathrm{f}$ (transl. from Biblica 43 (1962) 295-315); Pury, art. cit. 21.

${ }^{121}$ Müller, s. v. חכם , ThWAT 929, stresses the link between heart and wisdom (Ex. 28:3; 1 Ki. 3:12; Job 9:4; 37:24; Pr. 10:8; 16:21, 23; 18:15; Ec. 8:5).

${ }^{122} C f$. n.59. On this topic, A. de Pury, art. cit. 45 , observes: "La révélation de Yahvé n'a donc nullement entrainé une régression de la réflexion sapientiale ou 'philosophique'. Au contraire, elle a stimulé cette reflexion au point de l'amener à des formulations 'impensables' en Egypte ou en Mésopotamie."

${ }^{123}$ Art. cit. 191. Cf. von Rad, Wisdom $72 \mathrm{f}$. 
a pan-sacral mentality, ${ }^{124}$ for it requires a clear distinction between Creator and creature, the fear of the LORD is the principle of demythologisation! And if cosmic law is not \&ud $\gamma \mathcal{}$ un or even $M a^{\prime} a t,{ }^{125}$ if it is created order which a free Deity disposed, then one can understand how man, the image of God, can refuse or distort it. The distance between God and the world reflects itself in the freedom of man, and therefore in the possibility of two wisdoms. Pagan thought, with its latent pantheism, has been unable to set out the antithesis which is so decisive in Proverbs ${ }^{126}$ between folly and wisdom, between conceited destructive wisdom and that wisdom which the fear of the LORD teaches. The urgency in the motto comes from the existence of two rival appeals (Prov. 9) - so that we can say that the fear of the LORD (monotheism) explains why the fear of the LORD must be the principle of wisdom.

The function of wisdom in the harmony of the Old Testament, Lévêque expresses with the musical term counterpoint. ${ }^{127}$ It blends to the canto fermo which celebrates Covenant and redemption the other melody of God's origination of being and man's daily life. Paul Beauchamp uses the tools of structural analysis to show that prophecy and wisdom are correlative: the former corresponding to "now" and the latter to "always". ${ }^{128}$ We can comment that this very duality is based on creational monotheism: God upholds constantly the order of his creation (always) but remains free to intervene when and where it pleases him (now); as soon as one truth is denied, the other is totally altered. The queen of wise maxims expresses the vital bond between the two.

${ }^{124}$ This is von Rad's insistence, Wisdom $58 \mathrm{f}$; for him the secular outlook was the novelty of David's and Solomon's reigns. Crenshaw, op. cit. $17 \mathrm{ff}$, rightly questions the idea that pan-sacralism was the case in Saul's time and before.

${ }^{125}$ According to Ernst Würthwein, 'Egyptian Wisdom and the Old Testament' in Crenshaw (ed.), op. cit., 113-133 (transl. from German original, Marburg, 1960), $M a^{\prime}$ at as cosmic order is absolute, unchangeable, superior to the gods themselves. Has von Rad sufficiently distinguished between world order and divine Word? In Wisdom 156, they seem too closely identified; here Preuss' protest may be heard.

${ }^{126}$ The contrast fool/wise is a Biblical originality (Barucq, Proverbes 34); one may note also that whereas the tree of life is a common symbol, no clear correspondence for the tree of knowledge, and for the antithesis of the two trees, has hitherto been found in tales of origins.

${ }^{127}$ Art. cit. 191, 199f, and in the title.

128 'L'Analyse structurale et l'exégèse' VTSuppl 22 (1971) 124, $126 \mathrm{f}$. 
The Old Testament is patent in the New. Biblical theology cannot be satisfied with the exposition of a Theme in the Old Testament. Beyond the enrichment of wisdom reflexion on the fear of the LORD in Ecclesiasticus - the emphasis is on the Tora in which both wisdom and fear coincide - ${ }^{129}$ what becomes of the motto of Proverbs in the message of Jesus and the apostles?

Although it was eclipsed for a long time by the kerygma of Atonement and the Resurrection, and by the more frequent titles given to Jesus, the theme of wisdom has been attracting attention increasingly also in New Testament studies. André Feuillet, the $\varphi \iota \lambda \circ-\sigma \circ \varphi \delta$ s among New Testament scholars, has shown its presence and influence especially in the Gospels and in Paul's epistles. ${ }^{130}$ Jesus taught after the pattern of the sages: he stood unsurpassed in the art of משל ים and techniques of argument; his wisdom should have been recognised as greater than that of Solomon, the typical son of David, prince of peace (Mt. 12:42; Lk. 11:31). ${ }^{131}$ Far more, he suggested a mysterious oneness of himself and wisdom (Mt.

${ }^{129}$ Derousseaux, op. cit. 334ff.

130 'Jésus et la Sagesse divine dans les Evangiles synoptiques', $R B 62$ (1955) 161-196; Le Discours sur le Pain de Vie, Foi vivante 47 Desclee de Brouwer, Paris (1967), rep. from Nouvelle Revue Théologique (1960) and Etudes johanniques, Desclée de Brouwer, Paris (1962); Le Christ, Sagesse de Dieu d'après les épîtres pauliniennes, Etudes Bibliques, Gabalda, Paris (1966). A. van Roon, 'The Relation Between Christ and the Wisdom of God According to Paul' NovT 16 (1974) 207-239 launches on a ruthless critique of Feuillet's thesis; we have found him more convincing on 1 Cor. 2:9 and 1 Cor. 10:1ff than on other passages; his attempt to explain Paul's language in 1 Cor. 8:6 and Col. 1:15ff only by the use of Ps. 33 and 89, with no reference implied to Pr. 8 and later sapiential developments of Pr. 8, is not satisfactory (these sets of references do not exclude each other); van Roon's article is a useful reminder that there is no need to ransack non-canonical writings for parallels when there are better ones in the Old Testament. On wisdom themes in the New Testament, one can cite: François-Marie Braun, 'Saint Jean, la Sagesse et l'histoire' Neotestamentica et Patristica, Freundesgabe O. Cullmann, NovTSuppl 6 (1962) 123-133; Henry R. Moeller, 'Wisdom Motifs and John's Gospel' Bulletin of the Evangelical Theological Society (1963) 92-100; P.-E. Bonnard, La Sagesse en personne annoncée et venue: Jésus-Christ, Lectio divina, Cerf. Paris (1966); J. A. Kirk, 'The Meaning of Wisdom in James', NTS 16 (1969) 24-38.

${ }^{131}$ See already Dubarle, op. cit. 237ff; Hubbard, art. cit. 28f; recently Martin Hengel, The Son of God: The Origin of Christology and the History of JewishHellenistic Religion ET by John Bowden, SCM Press, London (1976) 74f; Hengel suggests that Jesus' logia were collected just as Solomon's sayings, and that this may well be the solution of the "riddle" of $Q$ (75 n.132). 
11:19; Lk. 7:35), and this near identification sheds much light on several aspects of his ministry ${ }^{132}$ Briefly summarized: just as wisdom in Proverbs 1-9 (and elaborations of this in Ecclus. 24 and 51 and Wisd.Sol. 7-9), Jesus sends forth messengers (Lk. 11:49; Mt. 23:34); just as wisdom, Jesus invites men to his banquet, (and in John 6, the food they are to assimilate is himself); just as wisdom, Jesus meets with scorn and opposition from sinners; just as wisdom, Jesus commends himself, and promises life to those who come to him, ${ }^{133}$ just as wisdom, Jesus enjoys the fullest intimacy with God, and knows him as only can a beloved child (Mt. 11:27; Lk. 10:22). In Paul's epistles, one can detect more than traces of a "wisdom christology": Christ Jesus "has become for us Wisdom from God" (1 Cor. 1:30); as Feuillet has shown, references are numerous in the Corinthian correspondence ${ }^{134}$ and when Paul had to counteract false doctrines of wisdom (Col.). Christ's part in creation (1 Cor. 8:6; Col. 1:15 ff.) Paul affirmed on the basis of Proverbs 8:22ff.: Christ is the ראשית of God's work, as also the Johannine writings testify (Christ the ópxń, Jn. 1:1ff; Rev. 3:14) and the Epistle to the Hebrews (1:3, echoing especially Wisd. Sol. 7). Main themes of Old Testament wisdom shine forth in the New Testament - what about its motto?

There is no distinct quotation or allusion to the saying of Proverbs 1:7 in the literature of the New Testament. The fear of God is far from being absent, and mainly denotes piety, ${ }^{135}$ sometimes with overtones of "sacred dread" (2 Cor. 5:11), yet it is nowhere called the principle of wisdom. Could it be that Christianity has no more use for the maxim?

This impression soon vanishes when one notes that the very texts are quoted which we considered to be perfect parallels of our maxim in prophetical books. In his discussion of wisdom (1 Cor. 1-2), Paul uses precisely Isaiah 29:14 and Jeremiah

${ }^{132}$ Ulrich Wilckens, s. $v$. $\sigma 0 \varphi i \alpha \quad u \tau \lambda \quad$ (N.T.), TDNT VII 515, grants that the idea Jesus = the Wisdom of God is "relatively early".

${ }^{133}$ Wilckens, ibid. 516, states that the yoke metaphor in Matt. 11:30 is for the concept of union with wisdom; Michael Maher, 'Take my Yoke upon You (Matt. xi.29)' NTS 22 (1975-1976) 97-103, rather stresses the authority of the New Moses.

${ }^{134}$ The main proof-text for Wilckens, ibid. $518 \mathrm{n} .376$ would be 1 Cor. 10:1-5. But see van Roon, art. cit. $228 \mathrm{ff}$.

${ }^{135}$ Horst Balz, s.v. $\varphi \circ \beta \varepsilon \omega \quad \dot{\varkappa} \tau \dot{\lambda}$ (N.T.), ThDNT IX op. cit. 208-217. 
9:22f (1 Cor. 1:19, 30). ${ }^{136}$ The general theme of God humbling the proud and exalting the lowly (Mt. 23:12; Lk. 1:51f; 14:11; 18:14; James 4:6,10; 1 Pet. 5:5f) is brought to bear on the subject of knowledge in the major wisdom passage of Matthew (11). True wisdom escapes the self-confident wise, God has hidden it from them, but it comes by revelation to the $\nu$ n $\pi \iota$ O $\iota$ who submit to the yoke of their humble teacher (vv. $25,27,29 f)$. Feuillet claims that $\nu n \pi \iota$ os is a wisdom term; it is used in several texts of the Greek Old Testament, ${ }^{137}$ and the most interesting instance is Psalm 19:9 (LXX 18:8) where the testimony of the LORD, parallel to the fear of the LORD, is called $\sigma \circ \varphi i \zeta o v \sigma \alpha$ v $\{\pi \iota \alpha$. The babes of Matthew 11 can be identified with those who fear the LORD in the Book of Proverbs, and so are not wise in their own eyes. The substance of the Old Testament maxim is there, and one could also point to John 8:31f (cf. 7:17) where Jesus promises the knowledge of truth upon condition of discipleship, or to the passages where Paul insists on the renewal of the mind, especially in its spirit, its basic disposition and motive (Rom. 12:2; Eph.

$4: 23$ ), always with the antithesis of the two wisdoms in the background. ${ }^{138}$

Why, then, is not the fear of the LORD mentioned? Derousseaux has seen that, generally speaking, Old Testament fear becomes New Testament faith. Several writers, whom we quoted, naturally slid to using the word "faith" in their explication of the wisdom saying. They should not be blamed. Coming to Christ, taking his yoke, receiving the Spirit which is from God, this is the equivalent of fearing the LORD, and it can be summarized in the word "faith". We suggest that fear can be translated faith because the critical element of "fear" belongs also to faith as soon as the Lord of faith is come down from heaven, a humble-hearted man and obedient unto death: when faith is in Christ and in him crucified, it pours contempt on human pride and it involves the denial of worldly wisdom. When wisdom, also, is not only

${ }^{136}$ Feuillet, Le Christ, Sagesse ch. I and II.

${ }^{137}$ Feuillet, Le Discours sur le Pain 85 n.105, gives many references, but among them only Pr. 1:32; Ps. 19:9 (LXX 18:8); 116:6 and 119:130(LXX 118:130) have the word vinilos.

${ }^{138} \mathrm{It}$ is present also in James (3:13ff), although the treatment is less "theological"; the warning against hybris is not forgotten either $(4: 6,10 ; c f .4: 13 \mathrm{ff})$. 
personified but is come in person, such is the concentration in him that faith becomes the all-inclusive word. This is how, in the New Testament, the fear of the Lord, - which, being interpreted, is faith in Christ, remains the principle of wisdom.

Conclusions close, but they may sometimes open. Ours will open a vista in another field of inquiry and raise the question: how has this message of the fear of the LORD, of faith as the principle of wisdom, been received in the Christian Church? We may suggest that the Augustinian tradition earnestly tried to honour it. Saint Augustine used a mis-translation of Isaiah 7:9 as he read: 'If you will not believe, you shall not understand', but he did not miss Isaiah's meaning. Saint Anselm followed in his train and his motto, fides quaerens intellectum, answers faithfully to the motto of the wise. Calvin opened his Institutes with the famous thesis that binds together the knowledge of God and the knowledge of man; of Calvin's theology we can say: its inspiration was in the fear of the LORD. And in our day, neo-calvinistic thought has exposed the fallacy of a would-be autonomous reason; it has shown the need of a Biblical ground-motive or determination for a sound world-view and rightful ethics. ${ }^{139}$

Whatever be the appraisal of these trends, the subject is relevant to the study of Biblical Theology. A. Barucq warns the modern scribes, his colleagues in Biblical scholarship, lest they deserve the LORD's rebuke in Jeremiah 8:8. ${ }^{140}$ The fear of the LORD is the principle of exegetical and theological wisdom. May only that which is faithful to this principle, in our contribution, be retained.

${ }^{139}$ We are thinking especially of the work of Herman Dooyeweerd and Cornelius Van Til (in spite of their later disagreements).

${ }_{140}$ A. Barucq, "Proverbs" DBS 1441. F. Michaëli, art. cit. 44 questions the concept of "scientific objectivity" in the light of the maxim. Even von Rad, Wisdom, 301 , notes the problem of the scholar's world-view being alien to that of the text. 